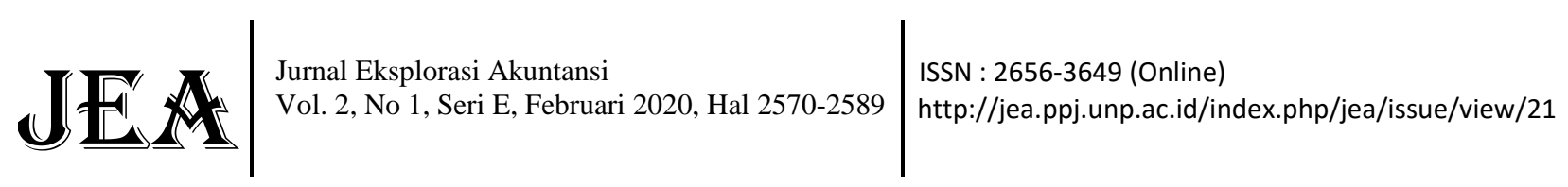

\section{STUDI FENOMENOLOGI AKUNTABILITAS DALAM PROSES KONVERSI BANK NAGARI SUMATERA BARAT MENJADI BANK NAGARI SYARIAH SUMATERA BARAT}

\author{
Wellya Fitri' ${ }^{1}$, Vanica Sherly ${ }^{2}$ \\ ${ }^{1}$ Alumni Jurusan Akuntansi Fakultas Ekonomi Universitas Negeri Padang \\ ${ }^{2}$ Jurusan Akuntansi Fakultas Ekonomi Universitas Negeri Padang \\ *Korespondensi: weliw545@gmail.com
}

\begin{abstract}
This research aims to investigate how members of the organization view the role of accounting and accountability in sharia entities before converting from convensional banks to sharia banks. This research is a type of phenomenological research. Data collection techniques are guided free interviews. The interview were conducted with employees of the Bank of Nagari Syariah Unit of West Sumatera and the sharia Unit of Payakumbuh branch. The results of this research proved that (1)The Imperfect implementation of Sharia accounting on Bank Nagari Syariah Unit of West Sumatera related to the concept of time period in terms of zakat reporting and withdrawal, thus making the implementation of the Islamic accounting system has not fulfilled the rules expected, (2) Low quality of human resources residing in the sharia branches related to sharia accounting and accountability, because they didn't realizing that the sharia system is run from the basic knowledge of sharia and sharia responsibility as a good Muslim, (3) Sharia units cannot fully run a Sharia products as a whole because is constrained by the capitalist rules that must be followed without any other options such as accounting concepts in monetary units, (4) The low level of public awareness that chooses to become a Sharia Bank client to fully carry out pure sharia from its own instinctively
\end{abstract}

Keywords: Syariah Accounting; Sharia accountability; Sharia banking conversion.

How to cite (APA $6^{\text {th }}$ style):

Fitri, W., \& Sherly, V. (2020). Studi Fenomenologi Akuntabilitas Dalam Proses Konversi Bank Nagari Sumatera Barat Menjadi Bank Nagari Syariah Sumatera Barat. Jurnal Eksplorasi Akuntansi, 2(1), Seri E, 2570-2589.

\section{PENDAHULUAN}

Perbankan Syariah adalah segala sesuatu yang menyangkut bank syariah dan unit usaha syariah, mencakup kelembagaan, kegiatan usaha, serta tata cara dan proses di dalam melaksanakan kegiatan usaha. Bank Syariah tidak mengenal "bunga". Imbalan bank syariah yang diterima maupun yang dibayarkan pada nasabah tergantung dari akad dan perjanjian yang dilakukan oleh pihak nasabah dan pihak bank. Perjanjian (akad) yang terdapat di perbankan 
syariah harus tunduk pada syarat dan rukun akad sebagaimana diatur dalam syariat Islam (UU No 21 Tahun 2008).

Perkembangan bank syariah di Indonesia semakin pesat dengan berkonversinya bank daerah menjadi bank syariah. Bank daerah pertama di Indonesia yang melakukan konversi menjadi bank syariah adalah Bank Daerah Aceh menjadi Bank Aceh Syariah. Konversi Bank Aceh disetujui oleh OJK pada tanggal 19 September 2016 dengan disahkannya izin operasional konversi ke syariah berdasarkan Keputusan Dewan Komisioner OJK Nomor. KEP44/D.03/2016 tanggal 1 September 2016 terkait Pemberian Izin Perubahan Kegiatan Usaha Bank Umum Konvensional menjadi Bank Umum Syariah. Setelah Bank Aceh, Bank NTB pun ikut melakukan konversi menjadi Bank NTB Syariah yang terlaksana pada bulan Agustus 2018 (Purba, 2017).

Seiringan dengan keberhasilan konversi Bank Daerah Aceh dan Bank NTB, Bank Pembangunan Daerah Sumatera Barat ikut memiliki rencana untumerubah sistemnya menjadi bank dengan sistem syariah. Hal ini ta lepas dari salah satu alasannya bahwa mayoritas masyarakat Sumatera Barat meruaan masyarakat muslim, sehingga Sumatera Barat merasa perlu mengadopsi sistem syariah dalam perekonomiannya. PT Bank Pembangunan Daerah (BPD) Sumatera Barat (Sumbar), Bank Nagari telah menetapkan diri untuk melakukan konversi menjadi bank bersistem syariah (sumbarfokus, 2019). Berdasarkan Rapat Umum Pemegang Saham Luar Biasa (RUPSLB) perubahan secara keseluruhan ditargetkan selesai pada 2021 mendatang. Menjelang itu, Bank Nagari diberi waktu untuk membenahi segala sesuatunya. Ketetapan untuk melakukan konversi ini bukan tanpa perencanaan. Hal ini sudah diproyeksikan jauh-jauh hari. Para pemegang saham sudah mengisyaratkan agar Bank Nagari melakukan kajian, memilih untuk konversi atau spin off. Ini karena pada 2023 nanti, memang sudah ketentuan Undang-undang bahwa setiap perbankan yang memiliki unit syariah harus membuat keputusan, pemisahan dengan spin off atau melebur dengan konversi.

Sebagai penguat dari perubahan sistem yang akan dilakukan Bank Nagari, Pemda Sumatera Barat telah memasukkan Perda tentang Bank Nagari yang dikonversi ke dalam salah satu dari 18 Perda yang akan diterbitkan pada tahun 2020. Namun sebelumnya Bank Nagari Sumatra Barat telah melakukan perluasan usahanya ke unit syariah. Sistem perbankan Bank Nagari Syariah mulai dibuka melalui Unit Syariah Bank Naga Sumatera Barat sejak 28 September 2006 (Bank Nagari/Annual Report, 2018). Selanjutnya kemurnian syariah yang akan diterapkan oleh Bank Daerah Sumatera Barat menjadi sesuatu yang dinanti, demi menyempurnakan kiprah menebar manfaat di Sumatera Barat pada khususnya, bahkan secara nasional pada umumnya. Hingga kini Unit Bank Nagari Syariah telah memiliki lima Kantor Cabang Syariah, empat Kantor Cabang Pembantu Syariah, dua Kantor Kas Syariah, dan 34 Layanan Syariah (Annual Report, 2018).

Perbankan yang melakukan konversi menjadi perbankan syariah harus memahami konsep dari akuntansi syariah. Akuntansi adalah proses mengidentifikasikan, mengukur dan melaporkan informasi ekonomi, untuk memungkinkan adanya penilaian dan keputusan yang jelas dan tegas bagi mereka yang menggunakan informasi tersebut (American Accounting Association), (Soemarso, 2009). Akuntansi syariah tidak hanya dianggap sebagai alat pencatatan atas transaksi-transaksi keuangan saja, tetapi Islam memberi nilai lebih untuk akuntansi syariah yaitu untuk mengembangkan dan menerapkan nilai-nilai syariat yang benar agar mampu mengkoordinir perekonomian yang bersih, halal, dan aman bagi penggunanya hingga ke akhirat kelak (Raini, 2017). Pada saat suatu perbankan memutuskan untuk berkonversi menjadi perbankan syariah maka pada dasarnya perbankan tersebut merubah sistem akuntansi konvensional menjadi akuntansi syariah untuk kemajuan perekonomian secara syariah. 
Salah satu tujuan utama akuntansi adalah untuk meningkatkan akuntabilitas. Dalam meningkatkan akuntabilitas manusia mengemban suatu amanah yang harus dilakukan sesuai dengan kenginan Allah SWT sebagai pemberi amanah (Triyuwono, 2006). Prinsip amanah lahir sebagai etika ekonomi yang bersumber dari nilai-nilai luhur dalam hukum Islam. Seperti istilah yang dipakai Triyuwono (2006) bahwa amanah adalah prinsip yang bersifat HumanisTransenden, dimana humanis diartikan hubungan manusia dengan manusia dan transenden adalah hubungan manusia dengan tuhannya. Prinsip inilah yang harusnya menjiwai setiap kegiatan dalam perbankan syariah untuk tercapainya akuntabilitas yang sempurna.

Disamping hubungan antara pemegang saham dengan manajemen, akuntansi syariah juga mencerminkan hubungan antara manusia dengan Allah SWT. Dimana Allah SWT merupakan pemilik dari semua asset yang paling berhak untuk menerima pelaporan yang benar, jujur, dan adil dari manusia yang menjalankan segala bentuk asetnya. Dari sini akuntansi syariah memerlukan teori yang disebut sebagai Syariah Enterprise Theory yang akan menggambarkan etika yang komprehensif dan dapat menentukan bagaimana bisnis harus dilakukan, bagaimana bisnis harus diatur, dan bagaimana pelaporan keuangan harus dibuat. Dalam perbankan syariah tidak hanya hubungan antara partisipan yang terkait langsung atau partisipan yang memberikan kontribusi kepada operasi perusahaan perusahaan (pemegang saham, kreditur, karyawan, pemerintah) saja yang penting, tetapi keterlibatan pihak lain yang tidak tekait secara langsung terhadap operasi perusahaan juga sangat penting. Sehingga, Syariah Enterprise Theory akan membawa kemashalatan bagi stockholders, stakehoders, masyarakat dan lingkungan alam tanpa meninggalkan kewajiban penting terhadap Allah SWT.

Ada beberapa penelitian yang membahas mengenai pentingnya akuntansi dan akuntabilitas pada proses konversi bank konvensional menuju bank syariah. Diantaranya, penelitian Rahim dan Goddard (1998) menyatakan bahwa peran akuntan dalam organisasi itu bermakna hanya sebagai praktik organisasi, tetapi tidak meningkatkan akuntabilitas mereka. Penelitian Walker (2002) juga mengatakan bahwa Akuntansi dianggap tidak lebih dari sekedar teknologi untuk mencatat informasi akuntansi dan keuangan saja, dan peran akuntan telah direduksi menjadi peran pembukuan. Penelitian Carmona dan Ezzamel (2006), sejalan dengan pernyataan tersebut bahwa terdapat hubungan yang pasti antara akuntansi dan agama. Bahkan Hamid (2009) memukan dizaman khalifah umar bin khatab ketika seorang pejabat ditunjuk, inventarisasi semua harta miliknya harus diambil. Jika ada peningkatan dalam kepemilikannya atau dalam posisi keuangannya secara keseluruhan, maka penyelidikan atas masalah tersebut harus dilakukan dan kepemilikan tambahan biasanya disita. Ini menunjukkan bahwa akuntansi dan akuntabilitas telah dipraktikkan sejak awal Islam berkembang.

Penelitian ini penting dilakukan karena dalam proses konversi perbankan syariah bank yang akan melakukan konversi tidak hanya sekedar menerima dan menjalankan perintah untuk konversi dengan mengacu pada segala aturan-aturan yang berlaku saja. Lebih dari itu pelaku konversi harus secara nurani memahi konsep dari sistem syariah itu sendiri, sehingga hal ini akan menjadi pondasi yang kuat bagi masing-masing pelaku konversi dalam menerima setiap aturan sistem syariah yang akan dijalankan pasca konversi menjadi Bank Syariah.

Perbedaan penelitian ini dengan penelitian sebelumnya adalah peneliti disini menggunakan objek penelitian sebuah lembaga keuangan daerah yang diikat oleh aturan dan kebijakan yang mutlak, sementara penelitian sebelumnya melakukan penelitian ini pada lembaga organisasi keagamaan yang tidak memiliki aturan dan kebijakan mutlak dari pemerintah. Selain itu fokus penelitian yang terdapat pada proses konversi bank daerah lainnya hanya sebatas respon dari pengguna jasa perbankan serta penerapan aturan pasca konversi, belum ada terdapat 
penelitian yang membahas masalah fenomena akuntabilitas dalam proses konversi bank umum menjadi bank syariah.

Secara khusus tujuan penelitian ini adalah untuk menyelidiki bagaimana pelaku konversi memandang peran akuntansi dan akuntabilitas dalam entitas syariah terutama dalam perbankan syariah. Hasil penelitian ini akan memberikan gambaran terhadap lembaga keuangan yang akan melakukan konversi serta pemerintah sejauh mana tingkat pemahaman pelaku konversi memahami akuntabilitas syariah sesuai dengan syariat yang benar, baik itu dari pusat maupun cabang. Oleh karena itu peneliti ingin melakukan penelitian ini pada Divisi Unit Syariah agar gambaran dari fenomena akuntabilitas syariah lebih riil dengan judul "Study Fenomenologi Akuntabilitas dalam Proses Konversi Bank Nagari Sumatera Barat menjadi Bank Nagari Syariah Sumatera Barat".

\section{REVIU LITERATUR}

\section{Teori Agency}

Teori Agensi (Agency Theory) merupakan teori yang menjelaskan tentang hubungan dua pelaku ekonomi yaitu prisipal dan agen. Hubungan keagenan adalah suatu kontrak dimana satu atau lebih orang (principal) mengikat orang lain (agent) untuk melakukan layanan atas kehendak mereka, dengan mendelegasikan kekuasaan beberapa pengambilan keputusan kepada agen. Agency theory menggunakan tiga asumsi sifat manusia yaitu: a) manusia pada umumnya mementingkan diri sendiri (self-interest), b) manusia memiliki rasional terbatas mengenai persepsi masa datang (bounded-rationality), dan c) manusia yang selalu tidak menyukai resiko (risk-averse) (Eisenhardt, 1989).

Menurut (Jensen dan Meckling, 1976) hubungan keagenan merupakan sebuah kontrak dalam bentuk pendelegasian wewenang dalam pembuatan keputusan keputusan yang telah diberikan oleh pihak pemilik (principal) kepada pihak perusahaan atau organisasi (agent). Pemilik merupakan pihak yang memberikan mandat kepada agen untuk bertindak atas nama prinsipal, sedangkan manajemen (agent) bertindak sebagai pihak yang diberi amanah oleh prinsipal untuk menjalankan perusahaan. Hubungan tersebut memberi konsekuensi, bahwa manajemen berkewajiban mempertanggungjawabkan apa yang telah diamanahkan oleh prinsipal.

Kegunaan informasi kini diragukan reliabilitas dan akuntabilitasnya terkait dengan fenomena Agency Theory (Scott, 1997). Hal ini sangat mungkin disebabkan oleh adanya rekayasa agen dalam menghindari resiko yang diakibatkan oleh ketidakmampuan menyajikan kinerja yang baik pada prinsipal. Dipihak lain, prinsipal sendiri tidak memiliki otoritas yang luas untuk asses informasi langsung pada perusahaannya. Dengan demikian sangat mungkin bahwa penyajian laporan keuangan untuk prinsipal dipenuhi dengan model window dressing.

\section{Teori Agensi Dalam Islam}

Hubungan prinsipal dan agen dalam Islam didasari dari konsep dasar amanah dalam kerangka kemutlakan tunggal atas kuasa Illahi. Amanah adalah sesuatu yang dipercayakan kepada orang lain untuk digunakan semestinya sesuai dengan keinginan yang mengamanahkan (Triyuwono, 1997). Ini artinya bahwa pihak yang mendapat amanah (pemilik perusahaan) tidak memiliki kewajiban penguasaan dari pemilikan mutlak atas apa yang diamanahkan. Pemilik perusahaan hanya berkewajiban untuk memelihara amanah tersebut dengan baik dan memanfaatkannya sesuai dengan yang dikehendaki oleh pemberi amanah, dalam hal ini adalah Tuhan sang pencipta alam semesta. 
Dalam perbankan syariah dan pengertian amanah, semua stakeholders dan karyawan yang ada harus mempunyai kesadaran yang tinggi akan sifat ketertiban dan kepasrahan kepada Allah SWT. Organisasi dalam pengamalan amanah memandang pemilik (principal) adalah pihak yang diberi amanah oleh Tuhan atas sumber daya yang dipunyai berupa dana atau keuangan untuk diolah sesuai dengan jalan Allah SWT, sedangkan manajer (agent) adalah pihak yang diberi kepercayaan oleh prinsipal untuk mengelola sumber daya tersebut dalam bentuk perusahaan. Dengan perspektif yang sama yaitu memandang bahwa manusia hanyalah seorang utusan Allah SWT maka baik manajer maupun pemilik sebagai pihak yang terlibat paling dominan dalam kelangsungan organisasi, tentu akan melakukan tugasnya masing-masing sesuai dengan perintah Allah SWT sebagai pemberi perintah tertinggi. Kesamaan perspektif tersebut memberi konsekuensi bahwa perusahaan dalam operasionalnya harus dijalankan sesuai dengan syari'at Islam (Elfianto, 2011).

\section{Syariah Enterprise Theory}

Akuntansi syariah tidak saja sebagai bentuk akuntabilitas (accountability) manajemen terhadap pemilik perusahaan (stockholders), tetapi juga sebagai akuntabilitas kepada stakeholder dan Allah SWT (Triyuwono, 2013). Syariah Enterprise Theory memiliki pandangan dalam distribusi kekayaan (wealth) atau nilai tambah (value added). Hal ini tidak hanya berlaku pada partisipan yang terkait langsung atau partisan yang memberikan kontribusi kepada operasi perusahaan (pemegang saham, kreditur, karyawan, pemerintah), tetapi juga terhadap pihak lain yang tidak tekait secara langsung terhadap operasi perusahaan. Oleh karena itu, Syariah Enterprise Theory akan membawa kemaslahatan bagi stockholders, stakehoders, masyarakat dan lingkungan alam tanpa meninggalkan kewajiban penting menunaikan zakat sebagai manifestasi ibadah kepada Allah SWT. (Slamet, 2011 dalam Triyuwono, 2013).

Syariah Enterprise Theory merupakan teori yang paling tepat untuk mencerminkan akuntansi dan akuntabilitas yang benar menurut Islam. Akuntansi adalah pusat Islam, karena pertanggungjawabannya kepada Allah SWT dan masyarakat maka semua kegiatannya sangat penting untuk iman seorang muslim. Berdasarkan hukum syariah Islam, etika yang komprehensif dapat menentukan bagaimana bisnis harus dilakukan, bagaimana bisnis harus diatur, dan bagaimana pelaporan keuangan harus dibuat. Kewajiban tersebut menimbulkan sinkronisasi yang tepat dengan Syariah Enterprise Theory.

Syariah Enterprise Theory relevan digunakan untuk perbankan syariah. Karena, dalam sebuah perbankan syariah tidak hanya hubungan antara partisipan yang terkait langsung atau partisan yang memberikan kontribusi kepada operasi perusahaan perusahaan (pemegang saham, kreditur, karyawan, pemerintah) saja, tetapi keterlibatan pihak lain yang tidak tekait secara langsung terhadap operasi perusahaan juga sangat penting. Sehingga, Syariah Enterprise Theory akan membawa kemashalatan bagi stockholders, stakehoders, masyarakat dan lingkungan alam tanpa meninggalkan kewajiban penting terhadap Allah SWT.

\section{Studi Fenomenologi}

Pandangan untuk memahami fenomena atau kejadian yang akan terjadi dalam kehidupan sehari-hari disebut sebagai fenomenologi. Dalam perjalanan hidupnya manusia sering mempertanyakan berbagai arti atau makna dari subjek yang dilihatnya (Siregar, 2005). Menyadari situasi ini maka muncul gagasan yang memperkenalkan suatu pemikiran filosofis sekaligus suatu metode untuk mencari arti atau makna dari berbagai fenomena yang akan terjadi 
karena individu tidak akan menciptakan makna dari apa yang dilihat atau dirasakannya, kecuali terdapat makna yang terkandung dalam berbagai fenomena itu sendiri.

Fenomenologi merupakan pendekatan yang menelaah fenomena tertentu dari sudut pandang partisipan. Penelitian fenomenologi memang berkutat pada makna yang muncul dari kehidupan sehari-hari subyek yang diteliti (Putra, 2013). Sementara fenomena itu sendiri adalah sebuah kenyataan sosial yang dialami oleh subjek yang bersangkutan, bukan fakta atau kenyataan. Tugas peneliti adalah melacak informasi selengkap mungkin dari partisipan mengenai suatu fenomena dan berupaya mendapatkan pemahaman yang tuntas mengenai makna fenomena tersebut bagi partisipan (Moedzakir, 2010).

\section{Prinsip Akuntansi Konvensional}

Akuntansi konvensional dipengaruhi oleh berbagai macam ideologi, akan tetapi dapat dilihat bahwa ideologi yang paling dominan mempengaruhinya adalah ideologi kapitalisme. Hal ini terlihat dari beberapa pendapat ahli akuntansi yang menjelaskan mengenai hal tersebut. Diantaranya, Harahap (2001) menyatakan bahwa ilmu akuntansi konvensional yang berkembang saat ini dilandasi jiwa kapitalisme dan sebaliknya perkembangan ekonomi kapitalisme sangat dipengaruhi oleh perkembangan akuntansi konvensional. Triyuwono (2001) mengatakan bahwa akuntansi saat ini bukan berbau kapitalis lagi, tetapi ia (akuntansi) adalah kapitalisme murni dalam pendapatnya.

Beberapa kelemahan sistem kapitalis ini adalah (Adnan 2005 Dalam Indriasih, 2010) : Pertama, ekonomi kapitalis adalah konsep yang human made, sama sekali tidak ada sentuhan Ilahiyah. Kedua, kapitalisme tidak mengenal kata keadilan yang seharusnya menjadi pilar utama dalam membangun sistem ekonomi yang solid. Ketiga, tidak manusiawi karena adanya eksploitasi baik dari manusia ke manusia lain, ataupun negara ke negara lain, Ketiga, telah terbukti bahwa penerapan konsep kapitalisme tidak otomatis memberikan kesejahteraan. Keempat, kapitalisme terbatas pada ukuran duniawi saja, kesejahteraan diukur dengan aspek materi dan kering dari nilai- nilai agama.

\section{Prinsip Akuntansi Syariah}

Nilai pertanggung jawaban, keadilan dan kebenaran selalu melekat dalam sistem akuntansi syari'ah. Ketiga nilai tersebut sudah menjadi prinsip dasar operasional dalam prinsip akuntansi syariah. Prinsip tersebut dijelaskan dalam surat Al-Baqarah ayat 282 yaitu:

1. Prinsip pertanggungjawaban

Prinsip pertanggungjawaban (accountability) merupakan konsep yang tidak asing lagi dikalangan masyarakat muslim. Pertanggungjawaban selalu berkaitan dengan konsep amanah. Bagi kaum muslim, persoalan amanah merupakan hasil transaksi manusia dengan sang khalik mulai dari alam kandungan manusia dibebani olehAllah SWT untuk menjalankan fungsi kehalifahan di muka bumi. Inti kekhalifahan adalah menjalankan atau menunaikan amanah. Banyak ayat Al-Qur'an yang menjelaskan tentang proses pertanggungjawaban manusia sebagai pelaku amanah Allah SWT dimuka bumi. Implikasi dalam bisnis dan akuntansi adalah bahwa individu yang terlibat dala praktik bisnis harus selalu melakukan pertanggungjawaban apa yang telah diamanatkan dan diperbuat kepada pihak-pihak yang terkait. 


\section{Prinsip keadilan}

Jika ditafsirkan lebih lanjut, surat Al-Baqarah;282 mengandung prinsip keadilan dalam melakukan transaksi. Prinsip keadilan ini tidak saja merupakan nilai penting dalam etika kehidupan sosial dan bisnis, tetapi juga merupakan nilai inheren yang melekat dalam fitrah manusia. Hal ini berarti bahwa manusia itu pada dasarnya memiliki kapsitas dan energi untuk berbuat adil dalam setiap aspek kehidupannya.

\section{Prinsip kebenaran}

Prinsip ini sebenarnya tidak dapat dilepaskan dengan prinsip keadilan. Sebagai contoh, dalam akuntansi kita kan selalu dihadapkan pada masalah pengakuan, pengukuran laporan. Aktivitas ini akan dapat dilakukan dengan baik apabila dilandaskan pada niali kebenaran, kebenaran ini kan dapat menciptakan nilai keadilan dalam mengakui, mengukur, dan melaporkan tansaksitransaksi dalam ekonomi. Dengan demikian pengembangan akuntansi Islam, nilainilai kebenaran, kejujuran dan keadilan harus diaktualisasikan dalam praktik akuntansi.

\section{Konversi Perbankan Syariah}

Konversi bank konvensional menjadi bank syariah telah dijelaskan dalam peraturan OJK NOMOR 64 /POJK.03/2016 Tentang Perubahan Usaha Bank Konvensional Menjadi Bank Syariah. Bank konvensional dibolehkan menkonversi kegiatan usahanya berdasarkan prinsip syariah dengan syarat mendapatkan izin dari Otoritas Jasa Keuangan (OJK) (lihat Pasal 4, 5, 6 \& 7 Undang-Undang No. 21 Tahun 2008 tentang Perbankan Syariah). Selanjutnya OJK mengatur syarat-syarat konversi tersebut dalam pasal 15, 16, dan 17.

Bank konvensional yang telah mendapat izin dan telah melaksanakan kegiatan usaha berdasarkan prinsip syariah tidak boleh lagi berubah menjadi bank konvensional. Bank konvensional tersebut wajib menyelesaikan hak dan kewajiban dari kegiatan usaha secara konvensional paling lambat 1 (satu) tahun terhitung sejak tanggal izin perubahan kegiatan usaha diberikan. Namun dalam kondisi tertentu yang tidak bisa dihindari (force majeur), maka penyelesaian hak dan kewajiban tersebut bisa diperpanjang (Pasal 18 Peraturan OJK 64 Tahun 2016).

\section{Konsep Dasar Akuntansi Dalam Perspektif Syariah}

\section{Entitas Ekonomi}

Entitas Ekonomi merupakan dimana akuntansi menganggap perusahaan adalah sebuah kesatuan ekonomi yang berdiri sendiri (AAOIFI, 1998), konsep ini bisa diterima karena dalam fiqh Islam mengakui bahwa organisasi adalah unit pertanggungjawaban yang terpisah dari entitas lain. Contohnya adalah lembaga wakaf, masjid, darul mal (treasury), dan juga lembagalembaga pemerintahan. Konsep diterapkan pada lembaga keuangan syariah karena manfaatnya yang jelas bagi lembaga keuangan syariah dalam mengalokasi zakat.

\section{Periode Waktu}

Konsep ini merupakan penilaian dan pelaporan keuangan perusahaan yang dibatasi oleh periode waktu tertentu, periodisasi sudah dikenal dalam Islam sebelum dikenalnya salah satu konsep dalam ilmu akuntansi. Konsep ini membantu dalam hal pembayaran zakat. Adnan dan Graffikin (1997), mengutip sebuah Hadits dalam mendukung pandangan ini di mana Nabi Muhammad SAW pernah berkata: 
“...dan tidak ada zakat pada harta sehingga berlalu waktu satu tahun” (HR. Abu Dawud).

Berdasarkan Hadits ini, setiap Muslim diwajibkan secara otomatis untuk menghitung kekayaan setiap tahun (periode) untuk mengetahui berapa jumlah zakat yang harus dibayarkan. Dalam pandangan peneliti, alasan-alasan penggunaan konsep ini untuk menghitung kekayaan sangat bisa diterima mengingat zakat juga punya kesamaan dalam hal haul (waktu perhitungannya).

\section{Penggunaan Unit Moneter (Monetary Unit)}

Konsep ini mengasumsikan bahwa tingkat daya beli dengan menggunakan unit moneter dianggap stabil. Penggunaan unit moneter sebagai faktor pengukur dapat diterima dalam pandangan Islam karena sebelumnya sudah dikenal adanya penggunaan emas dan perak sebagai unit pengukur (Ahmed, 1994). Secara syariah konsep ini tidak sesuai digunakan dalam kondisi keuangan dunia seperti sekarang di mana inflasi terus terjadi setiap waktu. Namun hal ini tidak dapat dihindari karena Indonesia sendiri belum memberlakuan pertukaran selain mnggunakan nilai mata uang.

\section{Biaya Historis}

Dengan konsep ini, kekayaan (assets) dicatat pada harga perolehannya atau yang setara dengannya. Kewajiban (liabilities) dicatat dengan jumlah pada saat terjadinya transaksi. Konsep ini sejak awal kemunculannya menuai banyak kritikan. Ada beberapa pendapat yang lebih memilih penggunaan nilai sekarang/pasar (current values) dibandingkan dengan historical cost, dengan alasan bahwa perhitungan zakat harus dilakukan dengan harga pasar Karim (1991), (Hamid et al, (1993), Sulaiman (2000) dalam Ibrahim (2009).

\section{Going Concen}

Konsep ini mengasumsikan bahwa suatu benda akan terus berlanjut sampai adanya bukti yang memperlihatkan kebalikannya. Dalam AAOIFI (1998) dijelaskan bahwa walaupun akad mudarabah dan musyarakah dibuat untuk jangka waktu tertentu, tetapi akad ini diasumsikan terus berlanjut sampai satu atau semua pihak yang terlibat memutuskan untuk mengakhirinya. Ahmed (1994) dalam Ibrahim (2009) berpendapat bahwa konsep ini tidak bertentangan dengan prinsip-prinsip Islam.

Menurut Ahmed, dalam figh Islam, ada satu konsep yang mirip dengan konsep ini yang disebut dengan istishab, yang bisa diartikan dengan retaining (berlanjut) atau accompaniment (tambahan). Konsep ini sesuai dengan ajaran Islam karena kontinuitas yang ada dalam konsep ini bukanlah abadi (indefinite) akan tetapi hanya berlangsung selama sesuatu itu ada. Islam juga menekankan keberlangsungan (continuity) aktivitas bisnis karena hal itu merupakan sumber zakat yang potensial yang harus dibayar tiap tahun.

\section{Pengungkapan Penuh}

Informasi keuangan pada umumnya tidak luput dari resiko penyajian yang dianggap kurang jujur dari apa yang seharusnya digambarkan (SAS, 2019). Hal tersebut bukan disebabkan karena kesengajaan untuk menyesatkan, tetapi lebih merupaka kesulitan yang melekat dalam mengidentifikasi transaksi serta peristiwa lainnya yang dilaporkan yang sesuai dengan makna transaksi dan peristiwa tersebut. Dalam kasus terentu, pengukrandampak keuangan dar suatu pos sangat tidak pasti sehingga entitas syariah pada umumnya tidak 
mengakuinya dala laporan keuangan. Namun dalam kasus lain, pngakuan suatu pos tertentu tetapdiangap relevan dengan mengungkap suatu resiko kesalahan sehubungan dengan pengakuan dan pengukuannya.

Pengeluaran zakat juga bisa dilakukan dengan benar jika konsep ini diterapkan dengan benar. Laporan keuangan harus memuat semua materi informasi yang diperlukan untuk membuat mereka berguna bagi users (para pengguna) (AAOIFI, 1998). Konsep ini sudah sangat sejalan dengan ajaran Islam yang menekankan pada aspek kejujuran sehingga para pengguna dapat mengetahui jenis-jenis informasi yang diperlukan tanpa mengandung penipuan.

\section{Akuntabilitas Dalam Islam}

Akuntabilitas merupakan konsep mengenai perilaku untuk mengawasi pihak lain, untuk menilai apakah mereka telah memenuhi tanggung jawab mereka, dan untuk menerapkan sanksi jika mereka belum memenuhi tanggung jawabnya (Mashaw, 2006). Akuntabilitas berwujud sebagai kewajiban untuk memberikan laporan kepada orang lain, untuk menjawab berbagai pertanyaan tentang bagaimana sumber daya telah digunakan dan apa dampaknya yang dihasilkan (Trow, 1996).

Islam mengembangkan konsep akuntabilitasnya sendiri atau biasa disebut dengan istilah Taklif (Al-Safi, 1992 dalam Anshori, 2010). Istilah Taklif berarti bahwa semua muslim bertanggung jawab atas perbuatan mereka pada hari pengadilan Allah SWT. Setiap orang bertanggung jawab atas perbuatannya sendiri dan setiap orang memiliki 'buku' daftar tindakan yang berisi semua perbuatan mulai dari yang kecil hingga ke yang besar semua dituliskan. Allah SWT akan membawa semua orang pada kehidupan dibangkitkannya manusia setelah mati dan membawa mereka dari kuburan mereka sehingga masing-masing dari mereka akan memenuhi hasil dari perbuatannya, dengan hukuman (Al-Safi, 1992 dalam Anshori, 2010).

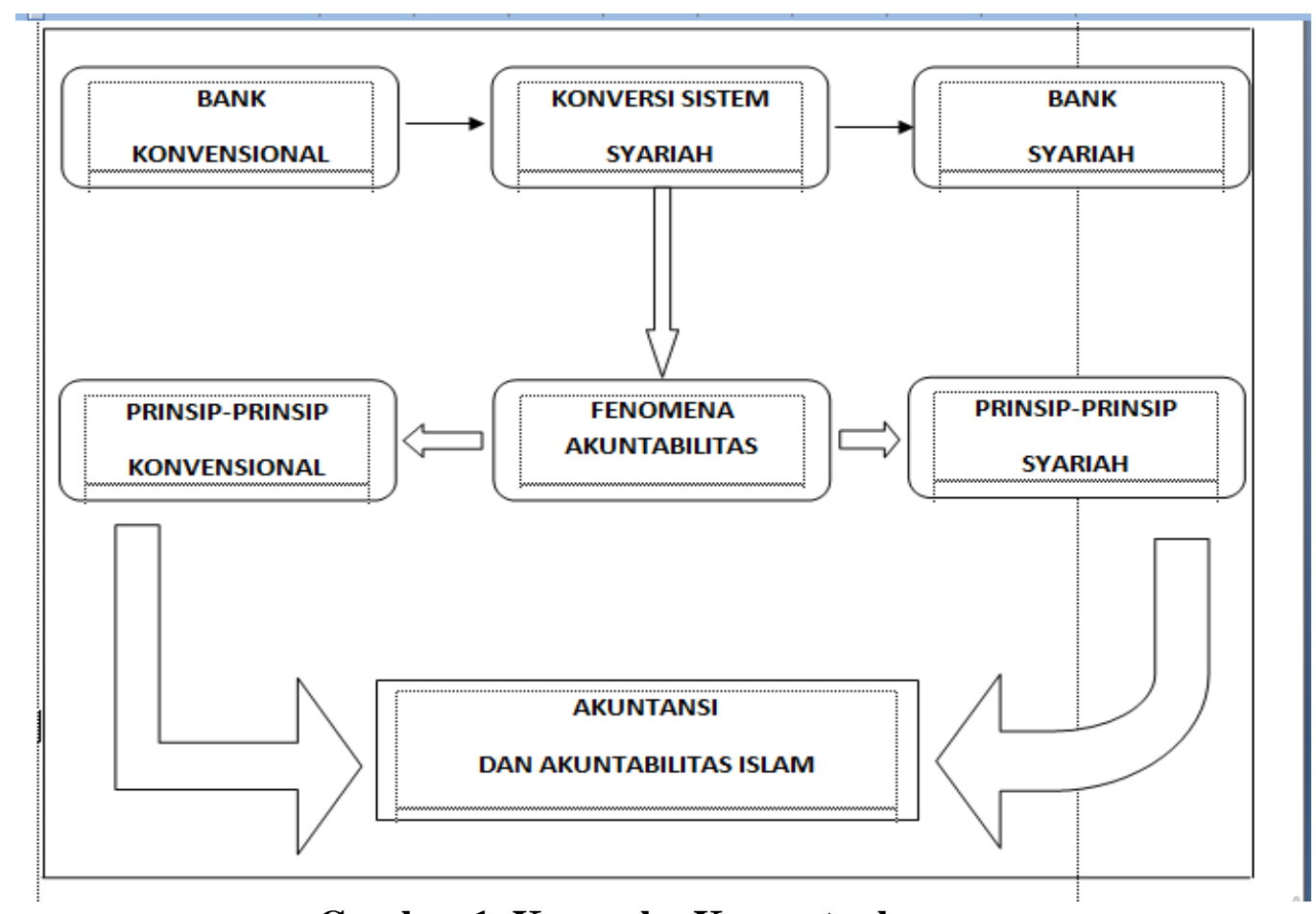

Gambar 1. Kerangka Konseptual 


\section{METODOLOGI PENELITIAN}

\section{Jenis Penelitian}

Jenis penelitian ini menggunakan fenomenologi sebagai pendekatan penelitian. Menurut Husserl dalam (Surahman, 2012) penelitian fenomenologi menggambarkan makna pengalaman informan akan fenomena yang sedang diteliti. Dengan demikian, perhatian haruslah terpusat pada fenomena itu tanpa ada praduga apapun. Penelitian fenomenologi mengajak orang lain menyaksikan langsung fenomena yang bersangkutan atau menunjukkannya melalui bahasa. Untuk memahami suatu gejala secara tepat harus menyelami bahasa yang diungkapkannya (Hasbiansyah, 2008). Penelitian ini mencoba mengungkap fenomena saat ini terkait kesiapan pelaku konversi Bank Nagari Smatera Barat menjadi Bank Nagari Syariah menyangkut Akuntabilitas Syariahnya yang dilihat dari sudut pandang anggota Divisi Unit Syariah Bank Nagari Sumatera Barat.

\section{Lokasi Penelitian}

Penelitian ini dilakukan pada Unit Syariah Bank Nagari Sumatera Barat yang berkantor di kota Padang. Pemilihan Bank Nagari Sumatera Barat sebagai tempat penelitian karena Unit Syariah Bank Nagari Sumatera Barat merupakan unit terpenting untuk menggambarkan kesiapan Bank Nagari Sumatera Barat untuk melakukan konversi ke sistem perbankan syariah dengan dasar pemikiran Unit Syariah ini telah lebih dulu memulai mengoperasikan sistem syariah dalam operasionalnya.

\section{Objek Penelitian}

Objek penelitian merupakan suatu atribut atau sifat atau nilai dari orang, objek atau kegiatan yang mempunyai variasi tertentu yang ditetapkan oleh peneliti untuk dipelajari dan kemudian diambil kesimpulanya (Sugiyono, 2012). Objek penelitian pada skripsi ini adalah karyawan Divisi Unit Syariah yang telah berpengalaman dalam menjalankan operasional perbankan syariah sehingga dianggap lebih berkompeten dalam proses konversi Bank Nagari Sumatera Barat menjadi Bank Nagari Syariah

\section{Jenis Dan Teknik Pengumpulan Data}

Dilihat dari cara memperolehnya data ini digolongkan pada data primer yaitu data penelitian yang diperoleh secara langsung dari pihak lapangan melalui kuisioner dan wawancara mendalam. Seperti yang dikatakan Moleong dalam Wahyuni (2000), bahwa kata-kata atau ucapan lisan dan perilaku manusia merupakan data utama atau data primer suatu penelitian.

Teknik pengumpulan data adalah dengan wawancara. Wawancara adalah percakapan dengan maksud tertentu yang dilakukan oleh dua pihak. Yaitu, pewawancara (interviewer) yang mengajukan pertanyaan dan terwawancara (interviewee) yang memberikan jawaban atas pertanyaan itu dengan maksud untuk mengkonstruksi mengenai orang, kejadian, organisasi, perasaan, motivasi, tuntutan, kepedulian dan lain-lain (Moleong, 2007).

Dalam penelitian ini peneliti menggunakan wawancara bebas terpimpin yaitu pewawancara menggunakan interview guide atau pedoman wawancara yang dibuat berupa daftar pertanyaan, tetapi tidak berupa kalimat-kalimat yang permanen (mengikat). Susunan pertanyaan dan susunan kata-katanya dalam setiap pertanyaan dapat diubah pada saat wawancara disesuaikan dengan kebutuhan dan kondisi pada saat wawancara, termasuk karakteristik sosial budaya (agama, suku, gender, usia, tingkat pendidikan, pekerjaan, dan sebagainya) informan yang dihadapi (Ghoni, Fauzan, 2012). Pertanyaan yang diajukan dalam wawancara akan 
dikembangkan saat proses wawancara sesuai kebutuhan karena wawancara ini merupakan wawancara bebas terpimpin.

\section{Teknik Analisis Data}

Untuk menganalisis data yang diperoleh dari hasil wawancara terhadap informan yang direkam menggunakan audio digunakan analisis data fenomenologis. Menurut (Stevick, 1971 Colaizzi, 1973 dan Keen, 1975 dalam Nayang, 2017) ada 4 tahapan analisis data fenomenologi yaitu:

1. Tahap awal

Peneliti mendeskripsikan sepenuhnya fenomena yang dialami subjek penelitian. Seluruh rekaman hasil wawancara mendalam dengan subjek penelitian ditranskripsikan ke dalam bahasa tulisan.

2. Tahap Horizonalization

Dari hasil transkripsi, peneliti menginventarisasi pernyataan-pernyataan penting yang relevan dengan topik.

3. Tahap Cluster of Meaning

Selanjutnya peneliti mengklasifikasikan pernyataan-pernyataan tadi ke dalam tema-tema atau unit-unit makna, serta menyisihkan pernyataan yang tumpang tindih atau berulang-ulang.

4. Tahap deskripsi esensi

Peneliti mengonstruksi (membangun) deskripsi menyeluruh mengenai makna dan esensi pengalaman para subjek.Pada penelitian ini peneliti bertindak sebagai perencana, pengumpul data, analisis, penafsiran data, serta pelapor hasil penelitiannya. Jadi alat yang digunakan peneliti dalam melakukan penelitian ini yaitu peneliti itu sendiri yang dibantu dengan wawancara.

\section{HASIL DAN PEMBAHASAN}

\section{Konsep Dasar Akuntansi Syariah}

Bagi institusi-institusi keuangan syari'ah, adanya konsep dasar akuntansi merupakan hal yang sangat penting untuk meneliti kesesuaian konsep tersebut dengan hokum Islam. Konsep kontemporer dari akuntansi dibangun mengikuti pertumbuhan teori akuntansi di dunia Barat dalam hal pembangunan kehidupan ekonomi dan perubahan kebutuhan dari kelompok yang berbeda terhadap informasi akuntansi (Ahmed, 1994).

\section{a. Konsep Entitas}

Entitas Ekonomi merupakan dimana akuntansi menganggap perusahaan adalah sebuah kesatuan ekonomi yang berdiri sendiri (AAOIFI, 1998). Pemikiran modern memperluas konsep tersebut hingga ke perusahaan dan entitas lainnya yang sejenis seperti bank Islam. Maka dari itu sebagai pebankan yang menjalankan usaha dalam bidang syariah memang sudah sepatutnya paham dengan konsep ini dan menerapkannya dalam perbankan syariah, Bank Nagari Unit Syariah telah memakai konsep ini dengan pemahaman yang jelas mengenai konsep ini seperti yang dikatakan salah satu infoman bahwa :

"udah pisah, kita punya full banking sistem sendiri, karna kita masak sendiri ya harus sendiri, ngak bisa campur kan, kita sendiri-sendiri. Tinggal induk memberikan kita modal usaha sekian, kita menjalankan modal usahanya yang dari induk itu secara prinsip syariah, jadi terlepas dari sistem induk. Penggunaannya itu memang induk sudah mengasihkannya untuk kita, untuk usaha kita, kalau 
laporan nanti kita kan buat sendiri. Jadi sampai saat ini kita masih belum satu entitas yang terpisah, kita masih menjadi unit usaha syariah, jadi induk memberikan modal kerja silahkan ini digunakan dengan kuali atau masaklah dengan syariah, kalau nanti ada kekurangan induk nanti bisa bantu tapi kita akan bayar bagi hasil syariah" (Ibu. C sebagai karyawan senior dan berjabatan penting)

Seluruh responden yang peneliti wawancarai mengenai entitas ekonomi memberikan jawaban yang sama bahwa mereka memiliki entitas sendiri dalam hal pelaporan sesuai dengan konsep entitas ekonomi yang diajarkan dalam Islam. Hal ini mengambarkan sebagai lembaga keuangan syariah yang harus memiliki konsep akuntansi syariah yang benar Dan mereka menjalankan konsep ini sejak awal Unit Syariah Bank Nagari Sumaetera Barat mulai beroperasi.

\section{b. Periode Akuntansi}

Konsep ini merupakan penilaian dan pelaporan keuangan perusahaan yang dibatasi oleh periode waktu tertentu, periodisasi sudah dikenal dalam Islam sebelum ia dikenal salah satu konsep dalam ilmu akuntansi. Konsep ini membantu dalam hal pembayaran zakat. Seperti yang dikutip dalam sebuah Hadits yang mendukung pandangan ini di mana Nabi Muhammad SAW pernah berkata:

“...dan tidak ada zakat pada harta sehingga berlalu waktu satu tahun” (HR. Abu Dawud).

Berhubungan dengan hal ini Unit Syaiah Bank Nagari Sumatera Barat sendiri memang telah mengikuti konsep periode satu tahun dalam pelaporannya. Semua informan mengatakan bahwa mereka memang menggunakan konsep ini yang juga dipakai dalam konsep akuntansi konvensional. Seperti yang dikatakan dalam penelitian :

“.. periode akuntansi itu seperti periode pelaporan ya ? itu biasanya kan satu tahun berjalan ya, disini kita juga menggunakan periode akuntansi satu tahun berjalan, artinya pelaporan itu kita buat dalam satu tahun periode, baik itu konvensional ataupun syariah itu sama saja menurut saya sama-sama menggunakan periode satu tahun." (Bapak. A sebagai karyawan berjabatan penting yang tergolong junior dalam unit syariah)

Dari hasil keterangan responden diatas maka terlihat bahwa konsep Periode Akuntansi juga sudah dipenuhi unit syariah Bank Nagari Sumatera Barat, periode tidak berubah dari periode yang digunakan pada umumnya yaitu periode pelaporan satu tahun sekali. Namun disini unit syariah belum memenuhi pembayaran zakat dari laba tahunan yang mereka peroleh karena mereka masih beroperasi dalam bentuk unit yang berinduk pada Bank Nagari Sumatera Barat. Hal ini disampaikan langsung oleh responden seperti yang dikutip dibawah ini:

"untuk periode akuntansinya memang benar kita menggunakan periode akuntansi satu tahun sama seperti dengan yang berlaku di bank umum, namun untuk zakat sendiri kita belum kelola yang namanya zakat tahunan yang biasanya disebut haul ya dalam syariah yakni waktu perhitungan, karena seperti yang saya katakana tadi 
laba kita masih memberikan ke induk setiap tahun jadi untuk zakat kita pribadi belum ada pengelolaannya dalam periode satu tahun". (Bapak B sebagai karyawan biasa yang tergolong junior)

Dari keterangan tersebut terlihat bahwa Unit Syariah sendiri paham dengan ketentuan periode akuntansi tersebut namun belum bisa sepenuhnya menyempurnakan pelaksanaannya hingga ke zakat karena status mereka yang masih berupa Unit atau anak dari Bank Nagari Sumatera Barat sehingga menggaharuskan mereka untuk mengikuti beberapa aturan tertentu terkait dengan penyatuan laba pada Bank Induk di akhir periode pelaporan, namun jika unit syariah ini beroperasi sendiri dalam artian menjadi Bank Nagari Syariah Sumatera Barat maka zakat dengan sendirinya akan dialokasikan dari laba tahunan sesuai peraturan dari DSN MUI. Unit Syariah Bank Nagari Sumatera Barat mengakui bahwa mereka tetap mengeluarkan zakat mereka berupa zakat profesi dan zakat karyawan, seperti yang dikatakan responden berikut :

"Zakat yang berlaku bagi kami adalah zakat karyawan, zakat karyawan kita mengacu kepada peraturan, pemda dulu ya, jadi masing-masing kita setiap bulan dipotongkan zakat profesinya, itu dipotongnya tiap bulan, dan itu punya kebijakan tersendiri juga, devisi sumber daya manusia kita punya kebijakan tersendiri yang 2,5\% itu dari pendapatan kita, nanti ada pembagian, mungkin yang akan dikelola bank yang akan masuk ke baznas itu sekitar 1\%, nah yang 1,5\% diserahkan ke karyawan, kan dimasukkan ke tabungan zakatnya karyawan itu nanti terserah karyawan mau memberikannya ke siapa karna itu sudah menjadi kebijakan bersama bagi karyawan, jadi yang perusahaan belum ada zakatnya sendiri”.(Ibu C sebagai karyawan senior dan berjabatan penting)

Secara konsep Islam Unit Syariah paham betul bahwa setiap pendapatan yang diterima tetaplah dikenakan zakat yang harus dibayarkan, meskipun belum diatur secara tahunan namun secara pribadi mereka telah mempraktekan konsep Islam dalam membayar zakat atas profesi dan jabatan mereka, hal ini merupakan fenomena yang baik sebagai lembaga keuangan syariah.

\section{c. Satuan Moneter}

Konsep ini mengasumsikan bahwa tingkat daya beli dengan menggunakan unit moneter dianggap stabil. Penggunaan unit moneter sebagai faktor pengukur dapat diterima dalam pandangan Islam karena sebelumnya sudah dikenal adanya penggunaan emas dan perak sebagai unit pengukur (Ahmed, 1994). Secara syariah konsep ini tidak sesuai digunakan dalam kondisi keuangan dunia seperti sekarang di mana inflasi terus terjadi setiap waktu. Namun hal ini tidak dapat dihindari karena Indonesia sendiri belum memberlakuan pertukaran selain mnggunakan nilai mata uang.

Unit syariah sendiri mengakui dengan pasti bahwa konsep ini bertentangan dengan konsep akuntansi syariah namun sebagai warga negara Indonesia unit syariah tidak memiliki pilihan lain untuk tidak memakai konsep tersebut karena memang di Indonesia belum mengakui konsep pertukaran mengguakan dinar/dirham sebagai bentuk pertukaran yang paling adil dalam syariat Islam. Seperti yang dikatakan responden kami : 
“...bicara tentang satuan moneter dan aturan syariah memang tidak fair ya, semua orang menyadari akan hal itu, kita dalam Islam diajarkan menggunakan emas dan perak sejak Islam mengenal akuntansi, tapi ya balik lagi karena tidak ad konsep lain yang bisa kita pilih jadi mau tidak mau kita harus tetap menggunakan satuan moneter atau rupiah yak arena tidak mungkin kita bisa terlepas dari itu semua sementara Negara kita belum menggunakan emas dan perak dalam transaksinya”.(Bapak A Dari Kepala Bagian Trisuri)

Meskipun konsep ini belum terpenuhi sebagai salah satu konsep akuntansi syariah namun hal ini tidak akan mempengaruhi kesiapan Bank Nagari Syariah menuju Bank Nagari Syariah Sumatera Barat. Karena proses konversi yang dilakukan bertujuan untuk membentuk perekonomian yang syariah maka sesungguhnya hal ini tidak dapat dilakukan dengan instan, pengerjaannya harus berproses dan dari konsep-konsep yang bisa kita lakukan sesuai dengan kondisi yang ada dinegara Indonesia sendiri.

\section{d. Biaya Historis}

Dengan konsep ini, kekayaan (assets) dicatat pada harga perolehannya atau yang setara dengannya. Kewajiban (liabilities) dicatat dengan jumlah pada saat terjadinya transaksi. Konsep ini sejak awal kemunculannya menuai banyak kritikan. Ada beberapa pendapat yang lebih memilih penggunaan nilai sekarang/pasar (current values) dibandingkan dengan historical cost, dengan alasan bahwa perhitungan zakat harus dilakukan dengan harga pasar Karim (1991), (Hamid et al, (1993), Sulaiman (2000) dalam Ibrahim (2009). Konsep biaya historis merupakan implementasi dari prinsip kejujuran yang sangat dianjurkan dalam Islam dalam bermuamalah sebagaimana ditekankan dalam beberapa ayat al-Qur'an, seperti salah satu ayatnya :

"Hai orang-orang yang beriman, janganlah kamu mengkhianati Allah dan Rasul (Muhammad) dan (juga) janganlah kamu mengkhianati amanat-amanat yang dipercayakan kepadamu, sedang kamu mengetahui"'(QS 8:27)

Dalam prinsip ini suatu institusi diwajibkan untuk mencatat pembelian sebesar harga pada saat diperolehnya suatu barang, walaupun harga tersebut meningkat pada keesokan harinya, namun perjanjian tidak boleh berubah atas hutang yang telah dibuat pada saat akad dibuat.Unit Syariah Bank Nagari Sumatera Barat menggunakan konsep biaya historis dalam operasionalnya. Seperti yang dikutip dari wawancara responden berikut :

“...ya kita pakai biaya historis, apalagi kita syariah kan, biaya yang kita berlakukan dalam perjanjian atau akad dengan nasabah harus biaya pada saat transaksi itu berlangsung, dan akan seperti itu sampai nasabah menyelesaikan perjanjiannya atau akadnya dengan kita, kalau kita gunakan nilai wajar tentu itu tidak akan relevan ya dengan kondisi sebenarnya, dan itu sama saja dengan nasabah akan terdzolimi dengan hal itu...". (Bapak D sebagai karyawan berjabatan penting)

Konsep biaya historis sendiri sebenarnya memiliki kontroversi dikalangan pengguna akuntansi syariah, namun dengan jawaban dari responden diatas yang memakainya dalam hal pembiayaan terhadap nasabah membuat kita bisa memahami bahwa Unit Syariah secara konsep akuntansi syariah paham dengan pemilihan konsep syariah mereka, mereka tidak serta merta 
hanya mengikuti aturan saja tetapi mereka mengerti kenal Islam mengajarkan yang demikian. Hal ini disampaikan langsung oleh salah satu karyawan berjabatan penting di Unit Syariah Bank Nagari Sumatera Barat seperti yang diuraikan di bawah ini:

“...Dalam syariah juga terdapat hukum-hukum yang diatur untuk menjalankan ekonomi seperti hukum muamalah. Kalau di syariah tu kalau yang transaksinya tu jual beli, transaksionalnya sebanyak akad yang diperjanjikan, menjadilah dia sebagai nilai pokok, ndak boleh dilebih-lebihkan, seanyak itu sampai mati, jelas. Kalau di konvensional bisa dilebih lebihkan, mulai dari bunga, tu nanti ada aja kebijakan ditengan jalan yang soal kaikan pajak lah bisa dilebihkan ditengah jalan, pakai pula floating (bunga berjalan) nanti, boleh di konven seperti it, kalau di syariah berapa jumlah pokok dari awal maka akan teta segitu jumlah hutang bahkan sampai mati nanti..."(Bapak D sebagai karyawan berjabatan penting)

Fenomena seperti ini sebenarnya yang harus diperhatikan dalam lembaga keuangan syariah. Pemahaman terhadap akuntansi syariah harus lahir dalam hati setiap karyawannya, tidak hanya sebatas menjalankan aturan syariah yang diperuntukan oleh SAS atau DSN MUI sebagai pembuat dan pengawas syariah Indonesia sesuai dengan konsep Islam yang benar.

\section{e. Going Concern}

Konsep ini mengasumsikan bahwa suatu benda akan terus berlanjut sampai adanya bukti yang memperlihatkan kebalikannya. Dalam AAOIFI (1998) dijelaskan bahwa walaupun akad mudarabah dan musyarakah dibuat untuk jangka waktu tertentu, tetapi akad ini diasumsikan terus berlanjut sampai satu atau semua pihak yang terlibat memutuskan untuk mengakhirinya. Ahmed (1994) dalam Ibrahim (2009) berpendapat bahwa konsep ini tidak bertentangan dengan prinsip-prinsip Islam.

Menurut Ahmed, dalam fiqh Islam, ada satu konsep yang mirip dengan konsep ini yang disebut dengan istishab, yang bisa diartikan dengan retaining (berlanjut) atau accompaniment (tambahan). Unit syariah sendiri tidak membenarkan memakai konsep ini dan hal ini berarti mereka tidak menggunakannya, karena menurut mereka hal ini bertentangan dengan syariat Islam dan konsep ini jelas merupakan konsep kapitalis yang mejadi konsep pada Bank Konvensional pada umumnya. Seperti yang dikutip dari wawancara responden berikut :

“...untuk dibawakan dengan syariah tentu tidak sesuai ya, karna jika kita memandang hal ini dalam syariah artinya kita menjadi pengendali mutlak atas perusahaan, padahal disini ada Tuhan ya, kita dijaga dan diawasi oleh Allah SWT SWT, yang posisinya disini menjadi penentu segala kemungkinan yang ada itu. Jadi tidak sesuai menurut saya going concern ini dengan konsep syariah..."(Bapak A sebagai karyawan berjabatan penting)

Dari hasil keterangan tersebut maka dapat dikatakan konsep going concern tidak diadopsi unit syariah yang menandakan mereka telah beroperasi sesuai dengan konsep syariah yang seharusnya untuk mengikuti konsep bahwa lembaga syariah beroperasi sesuai dengan akad yang telah diperuntukan tanpa konsep mendahului Tuhan dalam hal menjamin keberlangsungan usahanya. Penjelasan serupa disampaikan responden dari karyawan biasa sebagai berikut : 
"going concern itu keberlanjutan perusahaan dalam jangka waktu yang panjang bahkan mungkin tak hingga ya, yang memposisikan perusahaan tidak akan berakhir dalam waktu dekat. Ini jauh dari nilai syariah menurut saya, apalagi saya sebagai staf dan dan operasional saya tidak setuju akan hal ini, mengapa ? karena pada dasarnya secara konsep saya sendiri akan bergantung pada jangka akad atau perjanjian yang dibuat nasabah, disitu bisa terlihat secara jujur sampai kapan keberlanjutan ini akan berjalan. Akad selesai artinya usaha kita selesai kecuali dengan akad lain atau menyambung akad baru, jadi semuanya tergantung pada akad bagi saya." (Bapak B sebagai karyawan biasa)

\section{f. Pengungkapan Penuh}

Informasi keuangan pada umumnya tidak luput dari resiko penyajian yang dianggap kurang jujur dari apa yang sehausnya digambarkan (SAS, 2019). Hal tersebut bukan disebabkan karena kesengajaan untuk menyesatkan, tetapi lebih merupaka kesulitan yang melekat dalam mengidentifikasi transaksi serta peristiwa lainnya yang dilaporkan yang sesuai dengan makna transaksi dan peristiwa tersebut. Dalam kasus terentu, pengukrandampak keuangan dar suatu pos sangat tidak pasti sehingga entitas syariah pada umumnya tidak mengakuinya dala laporan keuangan.

Namun dalam kasus lain, pngakuan suatu pos tertentu tetap diangap relevan dengan mengungkap suatu resiko kesalahan sehubungan dengan pengakuan dan pengukuannya. Unit syariah melakukan pengungkapan sesuai dengan yang diatur oleh DSN MUI mreka percaya DSN MUI telah membuat aturan sedemikian rupa dalam hal pengungkapan, DSN MUI tentu telah memiliki pertimbangan sendiri sesuai dengan syariah Islam untuk membuat aturan apa yang harus diungkap secara rinci dalam hal pelaporan terutamanya. Seperti yang dikutip dari salah satu responden :

"ya betul sekali, dalam syariah semua hal harus diungkap sepanjang itu penting untuk diketahui pengguna laporan. Laporan ini kan secara syariah juga sudah ada yang mengatur, pos-pos apa saja yang wajib untuk dilaporkan, situasi dan kondisi bagaimana suatu transaksi dilakukan pengungkapannya, jadi kita juga merujuk pada aturan tersebut, dan menurut saja aturan tersebut sudah memenuhi aspek pengungkapan yang disyariatkan islam ya, karna peraturan dibuat oleh DSN (Dewan Syariah Nasional) MUI juga merujuk pada syariat Islam kan, jadi saya rasa kitapun selama mengikuti dan mengacu kepada PAPSI (Panduan Akuntansi Perbankan Syariah Indonesia) tersebut sudah pasti konsep kita berbeda dengan konvensional dan lebih baik dalam pengungkapannya”.(Bapak B sebagai karyawan biasa)

Hal ini secara umum dapat diterima sebagai proses Bank Nagari menuju Bank Nagari Syariah, karena mengikuti aturan DSN MUI merupakan proses standar dari upaya mensyariahkan lembaga keuangan konvensional yang awalnya berkiblat pada aturan kapitalis.

\section{Konsep Dasar Akuntabilitas Syariah}

Mendalami karakter beberapa staf senior dan junior yang ada di Unit Syariah Bank Nagari Sumatera Barat penulis melihat adanya beberapa gambaran akuntabilitas unit syariah saat ini. Hal ini terlihat pada saat mereka mengatakan bahwa mereka bekerja sesuai dengan pola yang diarahkan kepada mereka bukan mengikuti hati nurani dalam bersyariah. Hal ini banyak dialami 
oleh mereka yang berada pada unit syariah dalam waktu yang singkat, sementara bagi yang telah senior atau memiliki jabatan penting pemahaman akuntabilitas syariahnya sudah cukup bagus. Mereka mengaku bekerja menggunakan hati nurani dan bahkan berada ditahap bahwa pekerjaan bagi mereka adalah wadah dalam beribadah kepada Allah SWT dan bukan semata-mata ikhtiar mencari rezeki semata. Berikut beberapa kutipan responden terkait akuntabilitas :

...” untuk tanggung jawab itu sebenarnya sama saja ya, kita menjalankan pekerjaan sudah ada koridornya yang jelas, waktu dikonvensional kita diatur oleh peraturan konvensional dan disyariah kita diatur oleh peraturan syariah, yang keduanya itu dikeluarkan oleh badan atau orang yang berbeda, jadi kita maknai selama kita bekerja itu mengikuti aturan yang sudah ditetapkan saat itulah kita menjaga rasa tanggung jawab kita terhadap pekerjaan.."(Bapak Dari Kepala Bagian Trisuri)

Jawaban responden di atas seolah mensyiratkan bahwa nilai akuntabilitas syariah belum sepenuhnya tertanam dalam dirinya, hal ini mungkin bisa berubah seiring berjalan waktu dengan proses yang panjang setelah menjadi syariah sepenuhnya mereka akan menyadari untuk siapa mereka bekerja dan kepada siapa mereka harus mempertanggungjawabkannya. Seperti pendapat salah satu responden senior kami di bawah ini :

..." kita ini orang yang bersyariat Islam sudah sepatutnya kita bekerja dan mencari rezeki sesuai syariat Islam kan, jadi itu ya, kalau kita bisa menjalankan syariat dalam keseharian mengapa harus memilih melanggarnya, ketenangan bagi diri saya juga sebenarnya.. "(Ibu C Dari Bagian Pengembangan)

Bagi mereka yang memahami konsep akuntabilitas sebenarnya sesuai syariat Islam mereka sadar bahwa akuntabilitas yang disyariatkan Islam itu adalah bekerja dengan fakta bahwa pertaggungjawaban adalah hal mutlak dari setiap tindakan manusia.

\section{Respon terhadap proses mensyariahkan Bank Nagari Sumatera Barat}

Setelah konsep akuntansi dan akuntabilitas syariah yang menjadi tolak ukur yang penting dalam proses konversi, kita juga perlu mengetahui bagaimana respon dari beberapa pihak menyambut rencana konversi ini. Hal ini bisa dilihat dari pemegang saham, karyawan atau staf Bank Nagari seta nasabah atau masyarakat pada umumnya.

..."unit syariah ini ada juga salah satunya untuk memberikan edukasi secara tidak langsung kepada masyarakat, bagi mereka yang berasumsi syariah itu sama dengan konvensional dan mereka mau dating kesini untuk membandingkan keduanya saya rasa justru disitu peran kita, coba kalau unit syariah ini tidak ada mereka akan selamanya berasumsi seperti itu, tapi dengan adanya unit syariah ini setidaknya ada yang memancing mereka untuk mau dan ingin menjawab asumsinya selama ini benar atau tidak seperti itu.."(Bapak A Dari kepala bagian trisuri)

Unit syariah Bank Nagari Sumatera Barat mencoba menjelaskan bahwa keberadaan mereka sebagai unit sebelum nantinya bisa menjadi bank nagari syariah seutuhnya tidak terlepas dari perannya untuk menmberikan edukasi dala upaya proses bank nagari menuju sayriah agar setelah menjadi bank nagari syariah masyarakat khususnya nasabah tidak memiliki pandangan 
yang seperti itu. Selain itu dalam proses menuju konversi staf atau unit syariah khususnya juga harus mendukung hal ini, karena tidak dapat dipungkiri pada saat Bank Nagari menjadi Bank Nagari Syariah kelak maka yang paling siap dengan kondisi ini adalah staf dari unit syariah nya sendiri yang telah lebih dulu menjadi lembaga syariah sebelum pada akhirnya benar-benar menjadi syariah seutuhnya.

\section{SIMPULAN, KETERBATASAN, DAN SARAN Simpulan}

1. Belum sempurnanya penerapan Akuntansi Syariah pada Unit Syariah Bank Nagari Sumatera Barat terkait dengan beberapa item yang peneliti teliti, seperti konsep periode waktu dalam hal pelaporan dan pengeluaran zakat, sehingga membuat penerapan sistem akuntansi Islam belum memenuhi kaidah yang diharapkan.

2. Rendahnya kualitas SDM yang berada pada cabang Unit Syariah terkait dengan Akuntansi dan Akuntabilitas Syariah, mereka mengaku bekerja atas dasar peritah semata dan mengikuti alur yang diarahkan saja tanpa menyadari bahwa sistem syariah dijalankan dari pengetahuan dasar akan syariah dan tanggung jawab syariah sebagai muslim yang baik.

3. Unit Syariah belum bisa sepenuhnya menjalan produk syariah secara keseluruhan karena terkendala dengan aturan-aturan kapitalis yang harus diikuti tanpa ada pilihan lain seperti konsep akuntansi dalam unit moneter, sehingga penggunaan unit moneter tetap membawa unit syariah Bank Nagari Sumatera Barat yang ingin bersistem syariah masih mengikuti sistem konvensional.

4. Rendahnya tingkat kepedulian masyarakat yang memilih menjadi nasabah Unit Syariah Bank Nagari Sumatera Barat untuk sepenuhnya menjalankan syariah murni dari nalurinya sendiri, sebagian besar mereka memilih syariah tetapi tetap menjadikan bank konvensional sebagai tolak ukur atas kemudahan yang mereka terima.

5. Kurangnya pemahaman karyawan Unit Syariah Bank Nagari Sumatera Barat terhadap Akuntabilitas Syariah yang benar-benar sesuai dengan konsep Akuntabilitas Islam, dimana semua pertanggungjawaban tidak semata diarahkan pada kewajiban pelaporan dan tuntutan pengguna laporan saja namun yang paling penting kepada Allah SWT yang memberi, melihat, dan pemilik tunggal atas segala asset yang bersifat titipan terhadap manusia yang mengelolanya.

\section{Keterbatasan}

1. Sumber data yang digunakan hanya melalui wawancara.

2. Karena keterbatasan biaya dan waktu, maka responden yang didapatkan untuk penelitian ini hanya satu perbagian yang ada di Divisi Unit Syariah, oleh sebab itu, hasil penelitian ini tidak untuk digeneralisasikan terhadap keseluruhan Bank Nagari yang ada di Sumatera Barat.

\section{Saran}

1. Penelitian Selanjutnya

a. Untuk peneliti selanjutnya saya sarankan untuk melakukan pengumpulan data bukan hanya dari wawancara.

b. Dengan keterbatasan pada penelitian ini, maka disarankan bagi penelitian selanjutnya untuk penelitian selanjutnya adalah sebaiknya pemilihan sampel lebih menyebar dan 
memilih masing-masing responden yang memiliki peran cukup penting terhadap divisi yang dipimpin. Pemilihan sampel akan lebih baik jika lebih bervariasi.

2. Pemerintah Kota Padang

a. Pemerintah kota hendaknya melaksanakan pelatihan tentang Akuntansi dan Akuntabilitas Syariah sesering mungkin, sehingga seluruh karyawan benar-benar paham hakikat yang sesungguhnya dari sistem perbankan syariah.

b. Pemerintah kota perlu menata kembali penempatan posisi dari karyawan dan menyesuaikan jabatan karyawan sesuai kompetensi dan pemahaman yang dimiliki.

c. Pelaksanaan sistem perbankan syariah seharusnya tidak dipandang sebagai bisnis dalam hal upaya memajukan dan menarik minat nasabah saja, akan tetapi sistem syariah dijadikan untuk membantu memberikan kemudahan dalam meringankan kesulitan masyarakat yang memerlukannya dan dengan niat menjalankan syariat sebagai bentuk ibadah dan kewajiban terhadap Allah SWT sebagai seorang muslim.

d. Pihak Bank Nagari Syariah harus lebih kreatif dan inovatif lagi dalam mensosialisasikan prinsip syariah setiap saat dan jangan pernah takut untuk melakukan suatu perubahan demi tercapainya tujuan jangka panjang pemerintah.

e. Pemerintah kota harus lebih aktif membasmi pemahaman-pemahaman dan budayabudaya yang melahirkan paradigma yang salah dari masyarakat terkait dengan sistem perbankan syariah yang masih melekat erat dan mempengaruhi proses dalam menanggalkan sistem kapitalis yang secara tidak sadar menjerat masyarakat dengan sangat dzolim.

\section{DAFTAR PUSTAKA}

Afrida R. 2017. Analisis Persepsi Terhadap Penerapan Prinsip Akuntansi Berdasarkan Surah Albaqarah Ayat 282. Skripsi. Universitas Islam Negeri Sumatera Barat

AAOIFI. 1998. 1Accounting and Auditing Standards for Islamic Financial Institutions .Manama, Bahrain: Accounting and Auditing Organization for Islamic FinancialInstitutions

Al-Safi, A. K. 1992. Accountability: Islam versus the Man-made Doctrines. Darul Fikr, Kuala Lumpur.

Alqur'an dan Terjemahannya. (1976). Departemen Agama RI, Jakarta : Bumi Restu

Abdul, G. A. (2008). Sejarah Perkembangan Hukum Perbankan Syariah di Indonesia dan Implikasinya bagi Praktik Perbankan Nasional. Jurnal Ekonomi Isla, II (2)

Adnan, M. A dan M. Gaffikin. 1997. The Shari'ah, Islamic Banks and AccountingConcepts and Practices. Paper presented at Accounting, Commerce and Finance: the Islamic Perspective International Conference, University of Western Sydney, Macarthur

Attiah, M. (1989). Financial Accounting Theory in Islamic Thought, Islamic Banks International Union, [English Translatio

Baiman, S. (1990). Agency research in management accounting: a Second look. Accounting, organizing, and Society, 15, 341-371

Baydon, N dan R. Willet. 2000. Islamic Corporate Reports. ABACUS , Vol. 36, No.1, 2000, pp. 71-90.

Carmona, S., and M. Ezzamel. (2006). Accounting and Religion: A Historical Perspective. Accounting History 11 (2), 117-127. 
Dewi I. (2010). Prinsip Akuntansi Konvensional vs Akuntansi Syariah. Universitas Pancasakti Tegal

E.A.Q. A. (1994). Accounting Postulates and Principles from an IslamicPerspectives. Review of Islamic Economics, 3(2), 1-18.

Eisenhardt, K. M. (1989). Agency Theory: An Assessment and Review. Academy of Management Review, 14(1), 57-74.

Elfianto. (2011). Agency Theori Dalam Perspektif Syariah. Universitas Taman Siswa Padang

Frianto Pandia. (2005). Lembaga Keuangan. Jakarta: PT. Rineka Cipta.

Januar E. P (2017). Kajian Teoritis Konsep Akuntilitas

Hamid, S. 2009. An Islamic Alternative? Equality, Redistributive Justice, and the Welfare State in the Caliphate of Umar (rta). www.renaissance.com.pk/Augvipo2y3.html. Accessed in 10 Oktober 2019.

Harahap, Sofian Syafri. 2003. The Disclosure of Islamic Values - Annual Report The Analysis of Bank Muamalat Indonesia's Annual Report. Managerial Finance.

Hasan B, K.A \&. Siti N. (2010). Towards Good Accountability: The Role of Accounting in Islamic Religious Organisations

Hassan, A. and Harahap, S.S. (2010), Exploring corporate social responsibility disclosure: the case of Islamic banks, International. Journal of Islamic and Middle Eastern Finance and Management, 3 (3), 203-27.

Heri S. (2007). Bank dan Lembaga Keuangan Syariah, Yogyakarta: Ekonisia

Idriyanssyah P. 2017. Pengaruh Perubahan Bank Umum Syariah Terhadap Minat Menabung di Bank Aceh Syariah Pada Masyarakat Kabupaten Aceh Tenggara

Jensen, Michael C., dan Meckling, W, H. (1976). Theory of the Firm: Managerial Behavior, Agency Costs and Ownership Structure, Journal of Financial Economics 3. 82-137.

Khan. M.A (1994). Accounting Issues and Concepts for Islamic Banking. Paper presented atthe International Conference on Developing Accounting Standards for Islamic Banks, London: IIBI, p. 9.

Lewis M. K. (2006). Accountability and Islam. The Fourth International Conference on Accounting and Finance in Transition, Adelaide.

Lewis, M. K. (2001). Islam and accounting (Feature Article). Accounting Forum 25(2), 103-127.

Novinawati. (2015). Perkembangan Perbankan Syariah Di Indonesia. JURIS , 14(2)

Maali, B., and C. Napier. (2007). Twenty five years of islamic accounting research: A silver Jubilee review. Paper presented at the 5th Asia Pacific Interdisciplinary. Perspectives on Accounting Conference, Auckland, Australia.

Majid. (2016). Accounting and Accountability in Religious Organizations: An Islamic Contemporary Scholars' Perspective. Kuala Lumpur

Sulaiman. M. (2000). Corporate Reporting from an Islamic Perspective. Akauntan Nasional, 1822. 